\section{Recurrent selection in papaya: An effective strategy for the continuous development of new cultivars}

\section{Messias Gonzaga Pereira ${ }^{1 *}$ and Renato Santa-Catarina ${ }^{1}$}

Abstract: Part of the success of a breeding program depends on the composition of the base population. Superior genotypes and unimproved dioecious varieties are sources of genes for traits of interest and excellent options for the formation of segregating populations. Here we describe the first cycle of recurrent selection (RS) in papaya and propose an effective strategy, unprecedented in the crop, to generate variability and new cultivars. Initially, the RS base population (UCP-CO) was developed with wide variability. Subsequently, $196 S_{1}$ progenies were obtained, evaluated in a trial, and the superior $40 \mathrm{~S}_{1}$ progenies were recombined. Among the traits of the selected progenies, high fruit yield (producing two to five fruits per axil) stands out. The $S_{1}$ progenies were recombined and their seed bulk corresponds to the base population for the second cycle (UCP-C1). The results of the first cycle demonstrate the genetic potential of this population for the development of superior cultivars, and the breeding strategy applied is promising.

Keywords: Genetic basis, genetic variability, genetic potential, fruit yield, fruit quality.

\section{INTRODUCTION}

Papaya (Carica papaya L.) tree is one of the most economically important fruit trees in the world's tropical and subtropical regions. Fruits are rich in vitamins $A$ and $C$, potassium, folate, niacin, thiamine, riboflavin, iron, calcium and fiber (Huerta-Ocampo et al. 2012). The fruits, as well as the papaya stem, leaves and roots, are used in a wide range of medical applications (Ming et al. 2008). Papaya is also used for the commercial production of papain, which is used mainly as a red meat tenderizer, and for the manufacture of beer and skin, warts and scars treatment (Ming et al. 2012).

Brazil stands out on the international scene as the third largest producer, with annual production of 1.2 million tons in 2019 , equivalent to $8.5 \%$ of world papaya production (FAOSTAT 2021). The Southeast and Northeast regions are the largest producers, especially the states of Bahia and Espírito Santo, which in 2019 together accounted for approximately $71 \%$ of the national production of papaya (IBGE 2020). Despite the relevance of this fruit tree for Brazilian agribusiness, its cultivation needs to be enhanced by developing cultivars with excellent fruit yield and quality, resistance to diseases and pests and adapted to different producing regions. New papaya cultivars are usually selected and developed via segregating populations, obtained through crossing/recombination
Crop Breeding and Applied Biotechnology 21(S): e381321S7, 2021 Brazilian Society of Plant Breeding. Printed in Brazil http://dx.doi.org/10.1590/198470332021v21Sa20

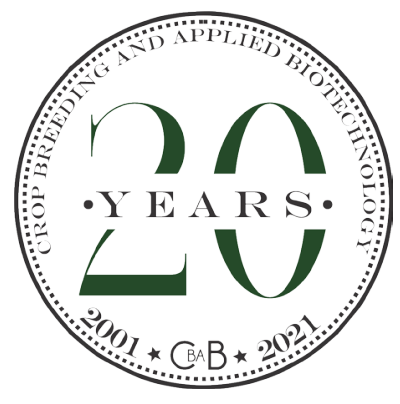

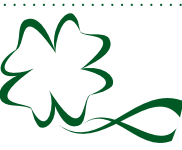

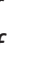

(n)


of genotypes with genes for traits of interest. The genetic variability in these populations allows the identification and selection of superior genotypes with traits of interest for the crop, such as disease resistance and fruit yield and quality (Cortes et al. 2019).

For papaya, different populations were developed and also submitted to and evaluated through some breeding method, such as the selection of genotypes from backcrossing populations for sexual conversion in papaya (Ramos et al. 2014, Barros et al. 2017, Santa-Catarina et al. 2019), the selection of genotypes from a bi-parental segregating population (Cortes et al. 2018, Miranda et al. 2021, Vettorazzi et al. 2021) and the development of the segregating population through recombination between contrasting genotypes for fruit yield and quality and for disease resistance (Santa-Catarina et al. 2020a, Santa-Catarina et al. 2020b).

Segregating populations of papaya are managed by different breeding methods, including the recurrent selection proposed by Hull (1945). This breeding method consists of gradually increasing the frequency of favorable alleles for quantitative traits, through repeated selection cycles, without losing the genetic variability in the population. The recurrent selection consists of three stages - progeny acquisition, evaluation and recombination - which are cyclically conducted until the frequency of the alleles of interest is satisfactory in the population (Hallauer et al. 2010).

During recurrent selection, the different genotypes are evaluated via digital image-based phenotyping (Cortes et al. 2017, Santa-Catarina et al. 2018) and several studies are possible, including the characterization of the base populations, for the identification of divergent genotypes, with favorable alleles for certain traits, where the multivariate analysis is one of the alternatives used in the characterization of these populations, aiming to estimate the genetic variability, patterns of variation and their genetic relationships between individuals in the population (Malik et al. 2014). In addition to characterization, the genotypes are selected through different methodologies, where the combined selection of several traits simultaneously is the most used in papaya (Silva et al. 2008a, Ramos et al. 2014).

Depending on the genetic constitution of the genitors used to obtain the segregating populations, such populations present variations in the pulp color of the fruits, i.e., yellow- or red-fleshed fruits, which the latter is the most accepted by the consumer market. Thus, throughout recurrent selection, selection is practiced to select phenotypes with a red pulp color, through planting, conduction and fruiting of the plants until fruit maturation, when the desired phenotype is identified, which requires larger areas to reach the goal. A more effective option is the use of molecular markers for early identification of plants with a certain phenotype, in this case, red pulp plants. In the nursery phase, in addition to the pulp color, it is possible to identify the sex via molecular marker, thus the evaluation areas will be composed only of hermaphrodite and red-fleshed plants.

Thus, the purpose of this study was to describe the conduction of the first cycle of recurrent selection in papaya, showing all the steps and results achieved, from the formation of the UCP-CO base population to the attainment of $\mathrm{S}_{1}$ progenies and selection of the superior $S_{1}$ progenies which were recombined and are being conducted aiming at the development of lines per se and/or hybrid lines. It also aims to demonstrate the use of molecular resources for the identification of sex and pulp color. Finally, the use of recurrent selection is proposed, which is an alternative established in various crops, but unprecedented in papaya.

\section{MATERIAL AND METHODS}

\section{Experimental location, organization and stages of the recurrent selection program}

All works related to recurrent selection in papaya are carried out in greenhouses and experimental fields, located in the Santa Terezinha Farm (lat 19 09' S, long 390 59' W, alt 30 m asl), owned by the company CALIMAN Agrícola S.A., in the city of Linhares, Espírito Santo, Brazil. The region's climate is classified as AWi (rainy tropical climate), with rainy summer and dry winter (Alvares et al. 2013).

The recurrent selection program in papaya started by developing an UCP-CO initial or base population (UENF Caliman Population Cycle 0) with a broad genetic base (Figure 1). The $S_{0}$ individuals of the UCP-CO population were phenotyped via digital imaging and at the same time self-fertilized to obtain the $S_{1}$ progenies. The $S_{1}$ progenies were then evaluated and the superior ones selected for recombination. After recombination, a bulk of seeds was formed which will correspond 
to the population for the second cycle of recurrent UCP-C1 selection. The next step will be the use of molecular tools to identify the sex and color of the pulp in the base population of the second UCP-C1 cycle. It is worth noting that until now the genetic material of the current population is segregating for pulp color, thus, in the UCP-C1 population, sex and pulp color will be identified early in the nursery phase, taking to the experimental unit only the phenotypes of interest, in this case, hermaphrodite and red-fleshed plants. At this stage, the yellow-fleshed phenotype of the recurrent selection population in papaya will be eliminated.

\section{Recombination to compose the UCP-CO base population}

In order to obtain the UCP-CO population, five dioecious progenies were used, namely: STA-22 (3), STA-05 (5), STA-17 (6), STA-02 (6) and STA-04 (5). These progenies were evaluated and identified as sources of genes for resistance to black spot in papaya, Asperisporium caricae (Speg.) Maubl. and to phoma-spot, Stagonosporopsis caricae (Sydow and P. Sydow) Aveskamp, Gruyter and Verkley [= Phoma caricae-papayae (Tar) Punith.] (Vivas et al. 2012, Vivas et al. 2013, Vivas et al. 2014). These progenies were recombined with five elite genitors - SS-72/12, JS- 12 , Sekati, 36/7 and 41/7 - with genes for fruit yield and quality. The SS-72/12 genitor belongs to the Solo group, with lower average fruit weight, while the other genitors have larger fruits, classified as the Formosa group. The genitors JS-12 and Sekati are contrasting for agronomic and sensory traits. The Sekati genitor produces large fruits, with excellent flesh firmness and moderate soluble solid content, while the JS-12 genitor differs from the Sekati for the last two traits, with moderate flesh firmness and high soluble solid content (Cardoso et al. 2014, Cortes et al. 2019). These five genotypes are genitors of commercial hybrids, registered at the Ministry of Agriculture, Livestock and Supply - MAPA (Luz et al. 2015, Luz et al. 2018a, Luz et al. 2018b, Pereira et al. 2019a, Pereira et al. 2019b, c).

The dioecious progenies and the elite genitors were sown in a greenhouse, using plastic trays with a capacity for 96 tubes of $55 \mathrm{~cm}^{3}$. "Tropstrato HT hortaliças" branded substrate and slow-release fertilizer Basacote mini $3 \mathrm{M}^{\circledR}$, NPK formula (Mg) 13-06-16 (1.4) with micronutrients: $0.0 ; 2.5 ; 5.0 ; 7.5 ; 10.0$ and $12.5 \mathrm{~kg} \mathrm{~m}^{-3}$. The seedlings were acclimatized about 20 days after germination and then planted in the experimental area on the 30th day. For each dioecious progeny, 10 planting pits were prepared with three seedlings each, totaling 50 pits and for the elite genitors; since they are genitors of commercial hybrids, they were planted in the company's seed production area. Both genotypes were planted with a spacing of $3.6 \mathrm{~m}$ between rows and $1.5 \mathrm{~m}$ between the plants in the line, totaling an area of $5.4 \mathrm{~m}^{2}$ per plant.

Genotype sexing was performed approximately 90 days after planting. For crosses, elite genitors were used as pollen donors and dioecious progenies as recipients. Thus, sexing was performed in dioecious progenies, and only one female plant remained in each planting pit. In the seed production area, elite genitor plants are sexed keeping both female and hermaphrodite plants, thus, the hermaphrodite plants were selected and used as pollen donors in this study. 
For the parental recombination, controlled pollination was performed, using a pollen mixture composed by 250 flowers from the elite genitors' hermaphrodite plants ( 50 flowers from each genitor). This pollen mixture was used to pollinate the flower buds of the female plants of the dioecious progenies, by using a brush (Figure 1). After pollination, female flowers were protected with a paper bag and identified with specific tags containing information about parental plants and pollination date. In this recombination process, it is important to emphasize that, due to the genetic constitution of the genitors, there was a sexual conversion of dioecious to gynodioecious plants, by replacing the sex chromosome $Y$ (male) by $Y^{\mathrm{h}}$ (hermaphrodite) (Ming et al. 2007).

About five months after controlled pollination, the fruits began to be harvested. For the formation of UCP-CO, four papaya fruits of controlled pollination of each dioecious progeny were considered, totaling 20 fruits. The seeds of these fruits were then grouped in equal amounts of 500 seeds, forming a bulk.

\section{Sowing of UCP-CO population, phenotyping of $S_{0}$ plants and attainment of $S_{1}$ progenies}

The bulk seeds were sown in a greenhouse, in plastic trays with a capacity of 96 tubes. About 20 days after germination, the seedlings were acclimated and then planted on the 30th day in the experimental area of the Santa Terezinha Farm, with a space of $1.5 \mathrm{~m}$ between the plants along the row and $3.6 \mathrm{~m}$ between rows. $260 \mathrm{~S}_{0}$ plants were identified, and only 222 of them have borne fruits and these were phenotyped and self-fertilized to obtain the $\mathrm{S}_{1}$ progenies.

For the phenotyping of $\mathrm{S}_{0}$ plants, the phenotyping methodologies based on the analysis and processing of digital images described by Cortes et al. (2017) and Santa-Catarina et al. (2018) were used. For field evaluations, images were obtained at 180, 270 and 360 days after planting, corresponding to the summer, autumn and winter seasons, or 90 days after anthesis (DAA), in each season evaluated. The plants were marked with a red colored wool to identify the last fruit evaluated in each bunch, in each evaluation period. In addition to the bunch, a label with information related to each treatment was attached. For laboratory evaluations, images were obtained at 270, 360 and 450 days after planting, in each season evaluated, when the fruits had the same RST1 (Ripening Stage T1) stage of maturation (Barragán-Iglesias et al. 2018).

The traits evaluated in the field tests were: plant height $-\mathrm{PH}$, expressed in $\mathrm{cm}$, measured from the base of the soil to the insertion of the last pair of leaves; first-fruit insertion height - FFIH, expressed in $\mathrm{cm}$, measured from the base of the soil to the first fruit insertion in the plant stem; stem diameter - SD, expressed in cm, measured at $20 \mathrm{~cm}$ from the base of the soil; number of deformed fruits - NDF, obtained by counting the number of deformed fruits; number of nodes without fruits - NNWF, obtained by counting the fruitless nodes, arising from sterility; number of commercial fruits - NCF, obtained by counting commercial standard fruits; fruit production - YIELD, expressed in kg plant ${ }^{-1}$, obtained by multiplying NCF by the average fruit weight. The PH, FFIH, SD traits were measured using the straight tool of the Image J software, while NDF, NCF and NNWF traits were obtained semi-automatically using the cell counter plugin of the ImageJ software.

The physicochemical traits examined in the laboratory were: fruit length - FL, expressed in $\mathrm{cm}$, obtained by measuring the length of the fruit, through image segmentation and use of the ImageJ software wand tool; fruit diameter - FD, expressed in $\mathrm{cm}$, by measuring the diameter of each fruit using the wand tool; ovarian cavity length - OCL, expressed in $\mathrm{cm}$, obtained by measuring the ovarian cavity using the straight tool; ovarian cavity diameter - OCD, expressed in $\mathrm{cm}$, obtained by measuring the ovarian cavity diameter using the straight tool; pulp thickness - PT, expressed in $\mathrm{cm}$, measuring the pulp thickness in each fruit, using the straight tool; and pulp volume percentage - \%PV, expressed as a percentage, obtained by the difference between the fruit volume and the ovarian cavity volume, both estimated according to Santa-Catarina et al. (2018).

The other traits such as fruit firmness - FF and pulp firmness - PF were measured by a digital penetrometer, Italy TR model, both expressed in $\mathrm{N}$ and were obtained by a sample of three perforations per fruit, both for the pulp and for the fruit. The soluble solid content - SSC, expressed in ${ }^{\circ}$ Brix, was obtained by using a portable digital refractometer, Mettler Toledo Refracto 30PX model. The average fruit weight - FW was obtained by weighing the fruits in a digital analytical scale, Toledo brand, model 9094. 


\section{Evaluation and selection of $\mathrm{S}_{1}$ progenies for recombination}

For the evaluation trial, $196 \mathrm{~S}_{1}$ progenies were considered and they were assessed in a $14 \times 14$ triple lattice design, with three replications and four plants per plot. The spacing applied was $3.6 \mathrm{~m}$ between rows and $1.5 \mathrm{~m}$ between plants in the row, totaling $12.700 .8 \mathrm{~m}^{2}$. Fertilization, management, pest and disease control and crop treatments were the same adopted in the commercial plantations of the company CALIMAN Agrícola S.A.

For the phenotyping of $S_{1}$ progenies, the same traits evaluated in the $S_{0}$ individuals from UCP-CO and the same phenotyping methodologies based on the analysis and processing of digital images described by Cortes et al. (2017) and Santa-Catarina et al. (2018) were considered.

The individual variance analyzes for the evaluated traits were performed according to the following statistical model: $Y_{i(j)}=\mu+t_{i}+r_{j}+(b / r)_{I(j)}+e_{i(j)}$. Where: $Y_{i(j)}$ is the observed value of treatment $\mathrm{i}\left(\mathrm{i}=1,2, \ldots, \mathrm{v}=\mathrm{k}^{2}\right)$, in the incomplete block $\mathrm{I}(\mathrm{l}=1,2, \ldots, \mathrm{k})$, of repetition $\mathrm{j}(\mathrm{j}=1,2, \ldots, \mathrm{r}) ; \mu$ is the constant inherent in all observations; $t_{i}$ is the effect of treatment $\mathrm{i} ; r_{j}$ is the effect of repetition $\mathrm{j} ;(b / r)_{I, j)}$ is the effect of repetition $\mathrm{j}$ within block $\mathrm{l}$; and $e_{i(j)}$ is the random error associated with the observation $Y_{i /(j)} \sim \operatorname{NID}\left(0, \sigma^{2}\right)$.

Due to virus-related problems in the papaya plant, there was a great loss of plants in the experimental area and the selection was conducted early, considering a larger number of progenies for recombination. In this case, the top $40 \mathrm{~S}_{1}$ progenies were selected based on the combined selection index proposed by Ramos et al. (2014). For selection, the $\mathrm{PH}, \mathrm{FFIH}, \mathrm{NDF}, \mathrm{NNWF}, \mathrm{NCF}, \mathrm{FW}$ and YIELD traits were used, assigning to these the agronomic weights $1,-10,-20,-20$, 100, 1 and 100 respectively. This relation of weights was established by experiment, based on the importance of the traits evaluated at the agronomic level, as suggested by Silva et al. (2008a). The combined selection of $\mathrm{S}_{1}$ progenies was based on the average of the families. For this purpose, the traits were multiplied by the agronomic weights described above, according to the equation below:

$$
I G_{2}=\left(V G_{t 1 \times p 1}\right)+\left(V G_{t 2 \times p 2}\right)+\ldots+\left(V G_{t n \times p n}\right)
$$

Where $V G_{t}$ are the standardized means for each trait, using the following equation: $\frac{\left(X_{g}-\overline{X_{g}}\right)}{S_{\overline{X_{g}}}}$, where $X_{g}$ is the value measured in the individual for variable $x, \bar{X}_{g}$ is the general mean of variable $x, S_{\overline{x g}}$ is the standard deviation and $p$ is the agronomic weight established for each trait.

\section{Recombination of superior $\mathrm{S}_{1}$ progenies}

Four months after the sowing in the competition trial of the $S_{1}$ progenies, the remaining seeds were sowed for the recombination of the superior 40 progenies. This strategy aims to reduce the time to obtain the first cycle of selection and constitution of the UCP-C1 population.

The progenies were planted in the experimental area of the company CALIMAN AGRÍCOLA S.A., in Santa Terezinha Farm. In the area for recombination, for each of the 40 progenies, 40 plants were planted in two blocks, one block with 15 plants of each progeny selected to receive pollen (female plants) and another block with 25 plants of each progeny used as pollen donors (hermaphrodite plants). During recombination, pollen from hermaphrodite plants of the superior $40 \mathrm{~S}_{1}$ progenies was collected, forming a pollen mixture. This mixture was then used to pollinate the female plants. In the end, equal amounts of seeds from the pollinated fruits were mixed to compose the population of the second cycle UCP-C1.

\section{Self-fertilization of superior $\mathrm{S}_{1}$ progenies to obtain $\mathrm{S}_{\mathrm{n}}$ progenies}

Parallel to the recombination of the superior $40 \mathrm{~S}_{1}$ progenies, they were self-fertilized to obtain the $40 \mathrm{~S}_{2}$ progenies. These progenies will be planted and self-fertilized in successive generations aiming at the development of superior $S_{n}$ lines.

These superior lines will be used in future studies as genitors of new hybrids. These will be tested in topcross with other unrelated lines belonging to the breeding program of papaya UENF/CALIMAN, such as lines from the sexual conversion of the dioecious genotype "Cariflora" (Silva et al. 2007a, Silva et al. 2007b, Silva et al. 2008a, Silva et al. 2008b, Ramos et al. 2011a, Ramos et al. 2011b, Ramos et al. 2014), which have shown excellent results in terms of combining ability for traits related to fruit quality and yield (Barros et al. 2017, Santa-Catarina et al. 2019). 


\section{Molecular markers as support for recurrent selection}

To start the second cycle, the UCP-C1 population will be sown in a greenhouse in the company CALIMAN AGRÍCOLA SA. The seedlings will be genotyped for sex and pulp color, using methodologies developed by our work team, which are in the final stages of testing with satisfactory results. Thus, in the cultivation area, all $\mathrm{S}_{0}$ plants from UCP-C1 will be hermaphrodite and will have red pulp color phenotype, and the $S_{1}$ progenies of the second cycle and with the desired phenotype will be obtained by self-pollination of the $S_{0}$ plants.

\section{RESULTS AND DISCUSSION}

\section{Genetic variability in UCP-CO}

The minimum, maximum and mean values for the 16 traits evaluated in the $\mathrm{S}_{0}$ plants of the UCP-CO population are shown in Figure 2. For all traits it is possible to observe a great oscillation between the maximum and minimum values, which demonstrates the existence of a wide genetic variability for all evaluated traits. The UCP-CO mean value for the $\mathrm{PH}$ was $222.73 \mathrm{~cm}$. In general, this mean value is within what is observed when compared to commercial genotypes. Cortes et al. (2017) found means for the PH trait equal to $224.85 \mathrm{~cm}$ for the traditional phenotyping and $224.91 \mathrm{~cm}$ for the digital image-based phenotyping, evaluating commercial cultivars. Another important trait in papaya are plants with higher SD. In general, plants with higher SD tend to support more fruits in the bunch, and consequently more productive
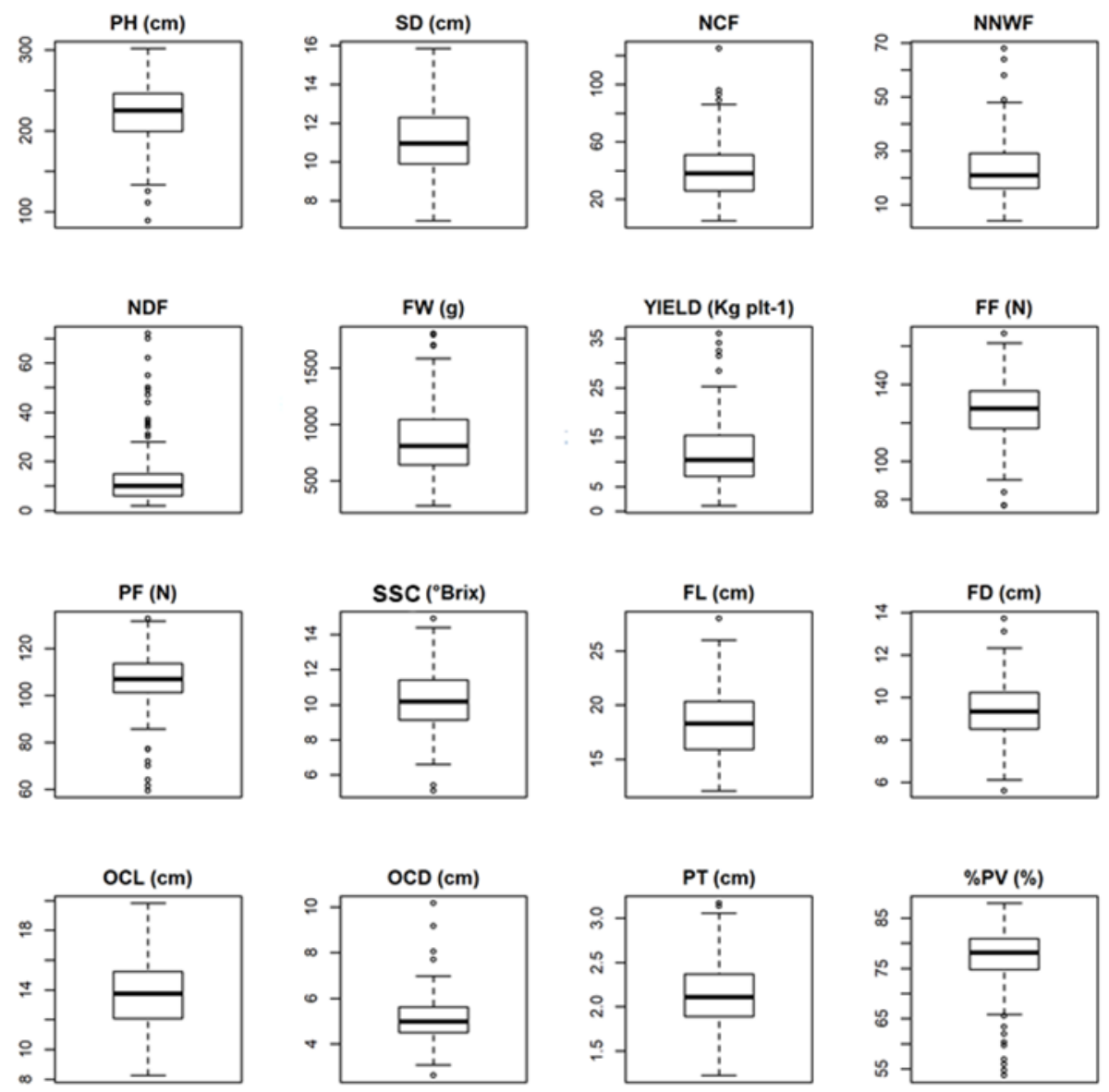

Figure 2. Boxplot with maximum, minimum and mean values for 16 traits evaluated in the $\mathrm{S}_{0}$ plants of the UCP-CO population. $\mathrm{PH}$ : plant height; SD: stem diameter; NCF: number of commercial fruits; NNWF: number of nodes without fruits; NDF: number of deformed fruits; FW: fruit weight; YIELD: Fruit production; FF: fruit firmness; PF: pulp firmness; SSC: soluble solid content; FL: fruit length; FD: fruit diameter; OCL: ovarian cavity length; OCD: ovarian cavity diameter; PT: pulp thickness; \%PV: percentage of pulp volume. 
(Silva et al. 2007b). The mean for SD at the UCP-CO was $11.3 \mathrm{~cm}$, and the maximum and minimum SDs observed were $18.85 \mathrm{~cm}$ and $6.96 \mathrm{~cm}$ respectively, showing that selection is possible for stem diameter, especially for the increase of it. Cortes et al. (2017), when evaluating papaya genotypes, found means similar to this study for the SD trait. Nascimento et al. (2019), evaluating 92 genotypes in $\mathrm{F}_{2}$ papaya population, found similar results for the PH and SD traits.

The papaya genotypes to be considered in the selection must be productive, with commercial standard fruits, and present a reduced number of nodes without fruits and fruits with deformations. For traits related to fruit yield such as NCF, NNWF and NDF, the mean values obtained in the UCP-CO were 39.99, 23.02 and 13.71, respectively. These traits are related to summer sterility, which increases during the hottest months of the year, while carpeloidy and pentandry (deformed fruit) rates increase in the coldest months of the year (Damasceno Junior et al. 2008). Luz et al. (2015) found lower means of 24.30, 14.98 and 0.66 for these same traits, respectively, when evaluated papaya hybrids. Moreira et al. (2019), in specific studies for summer sterility and for carpeloidy and pentandry rates, verified that the repeatability coefficients varied from low to intermediate due to the quantitative nature of the evaluated traits, which are highly influenced by environmental factors. For these traits, each cycle of recurrent selection seeks to reduce deformities and sterility and increase the quantity of commercial fruits in the population.

For traits related to fruit size such as $F L$ and $F D$, the results ranged from $12.12 \mathrm{~cm}$ to $27.99 \mathrm{~cm}$, with mean value of $18.26 \mathrm{~cm}$ for the FL trait and from $5.62 \mathrm{~cm}$ to 13.74 $\mathrm{cm}$, with mean of $9.42 \mathrm{~cm}$ for the FD trait. This relation between length and diameter is interesting in post-harvest because the selection is conducted aiming at fruits with appropriate size for packing in boxes for transportation in the national and international market. FW is another important trait, which ranged from 279.75 to $1808 \mathrm{~g}$ in the UCP-CO population, with a mean of $859.74 \mathrm{~g}$. This result is fantastic as it shows that the UCP-CO base population has sources for selection aiming at the development of genotypes with Solo-standard fruits (small fruits, around $500 \mathrm{~g}$ ), Intermediate and Formosa-standard fruits (large fruits, greater than $1000 \mathrm{~g}$ approximately), virtually covering the entire national and international consumer market.

The genotypes, in addition to being productive, must produce fruit with quality, and genotypes with higher mean values for the FF, PF, SSC and PT traits are desirable for selection. The means for these quality-related traits were $126.60 \mathrm{~N}, 106.91 \mathrm{~N}, 10.21^{\circ}$ Brix and $2.14 \mathrm{~cm}$, respectively. Individual UCPC015-165 had the highest mean for FF (166.70 N), UCPC015-247 for PF (132.93 N), UCPC015-209 for SSC ( $14.93^{\circ}$ Brix) and UCPC015-03 for PT $(3.17 \mathrm{~cm})$. In the UCP-CO population, the individual UCPC015-52 was the one that stood out for fruit quality, with means of 161.82 $\mathrm{N}, 125.61 \mathrm{~N}, 13^{\circ} \mathrm{Brix}$ and $2.57 \mathrm{~cm}$, for the FF, PF, SSC and PT traits, respectively. Santa-Catarina et al. (2019), evaluating papaya genotypes from backcrossing to sexual conversion, found the following means for the FF (112.12 N), PF (85.48 $\mathrm{N})$ and SSC (10.2 ${ }^{\circ}$ Brix) traits. Ide et al. (2009) observed a variation of 9.70 to $12.80^{\circ} \mathrm{Brix}$ when using testers to select hybrids that combine with high fruit yield per plant and with attributes related to fruit quality such as fruit and pulp firmness. It is noteworthy that in the UCP-CO the individuals evaluated present a source of alleles for the quality of fruits, which was already expected due to the

a

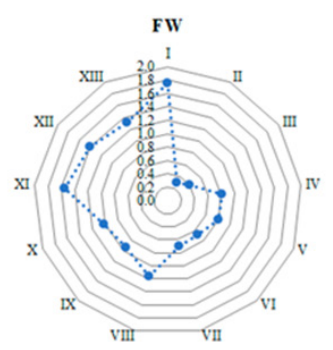

C

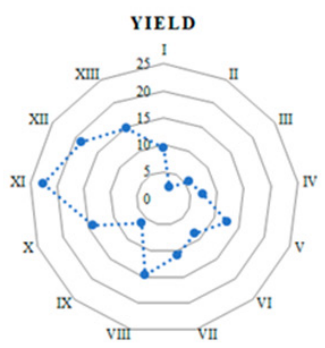

e

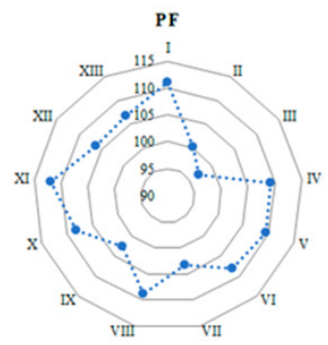

b

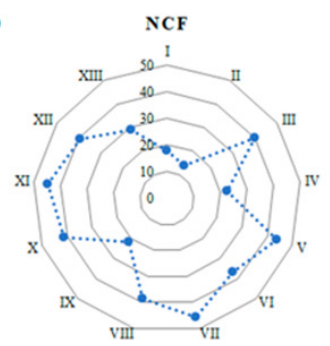

d
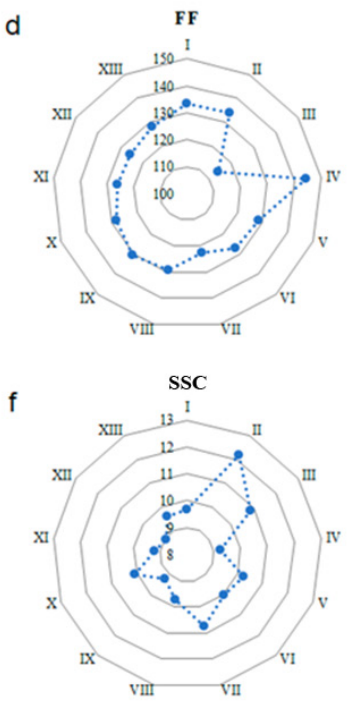

Figure 3. Plots of mean values of the six most important traits for the crop, according to 13 groups (I, II, III, IV, V, VI, VII, VIII, IX, $\mathrm{X}, \mathrm{XI}, \mathrm{XII}$ and XIII) formed by the UPGMA grouping. Lower means are observed at the centers, while the highest means are found at the extremes. a) Average fruit weight - FW (g); b) Number of commercial fruits - NCF; c) Fruit production - YIELD $\left(\mathrm{kg} \mathrm{plant}^{-1}\right)$; d) Fruit firmness - FF (N); e) Pulp firmness - PF (N); f) Soluble solid content - SSC ( ${ }^{\circ}$ Brix). 
genetic constitution of the genitors used in the recombination to form the UCP-CO population.

The cluster analysis based on the UPGMA method formed 13 distinct clusters among the $\mathrm{S}_{0}$ individuals of the UCP-CO population at a distance of 0.75 (CCC), based on all morphological traits and considering all the genetic variability of

Table 1. Mean, minimum, maximum and standard deviation values of the traits evaluated in the $40 \mathrm{~S}_{1}$ progenies selected for recombination

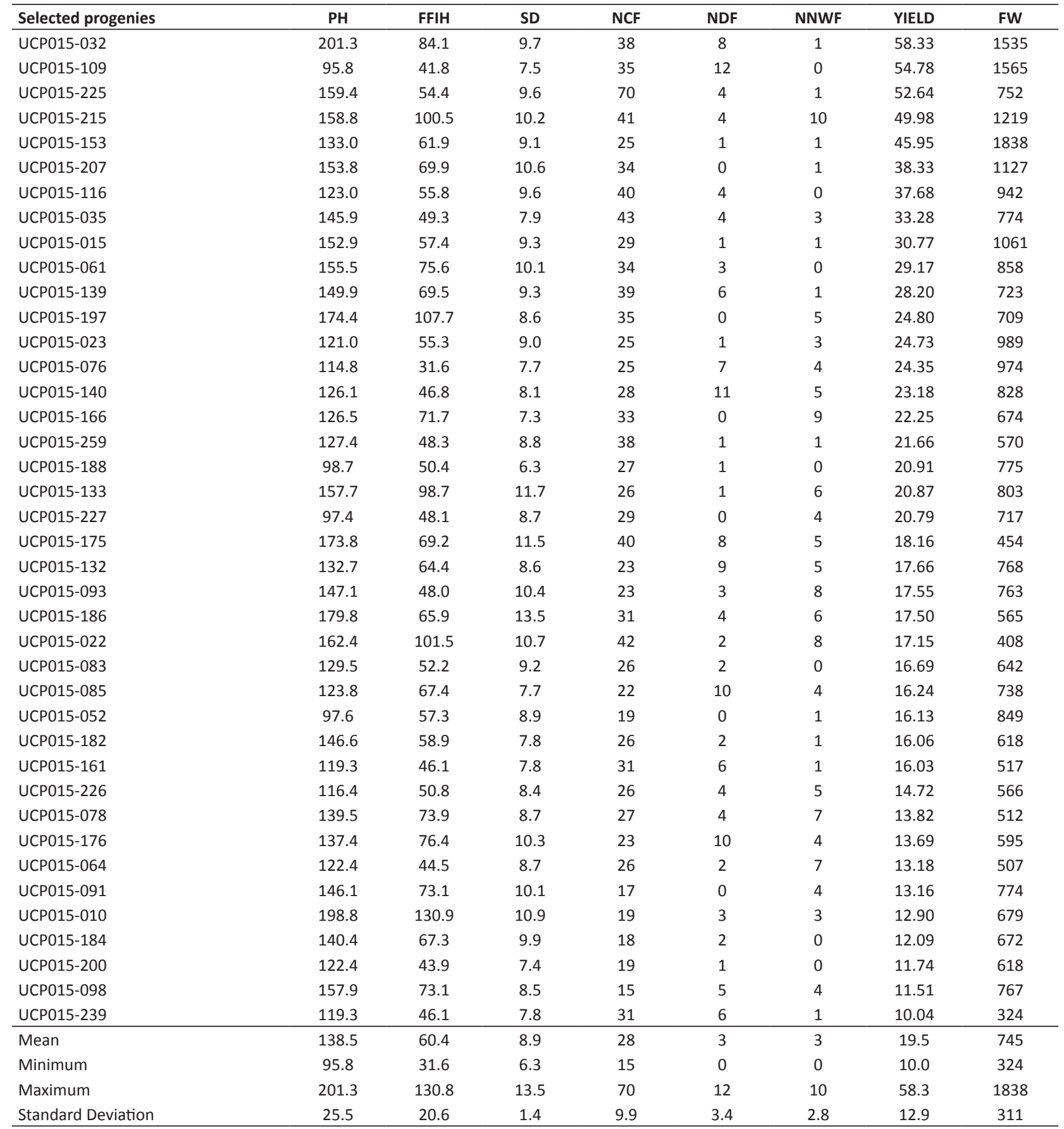

PH: plant height (cm); FFIH: first fruit insertion height (cm); SD: stem diameter (cm); NCF: number of commercial fruits; NDF: number of deformed fruits; NNWF: number of nodes without fruits; FW: average fruit weight (g); YIELD: fruit production ( $\mathrm{kg} \mathrm{plant}^{-1}$ ). 
the studied population. Figure 3 shows the means according to the relevant groups, for the NCF, FW, YIELD, FF, PF and SSC traits, considered as the most important for the crop. FW was the one that most contributed to the diversity and formation of groups, ranging from $305 \mathrm{~g}$ for group II to $1750 \mathrm{~g}$ for group I. Therefore, the formation of groups according to the FW is suggested. Considering the FW mean value in each formed group (Figure 3a), we identified groups IV, VI and XI that have plants with Solo-typical fruits, group VIII with plants producing Solo/Intermediate fruits, groups VII, $\mathrm{X}$ and XIII with plants producing Intermediate size fruits, group II with plants producing Intermediate to Formosa size fruits and groups I, III, V, IV and XII with plants producing Formosa-typical fruits.

Considering only the groups with Solo genotypes, the genotypes in group III had the highest means for NCF (Figure 3b) and YIELD (Figure 3c) traits, related to productivity, while the individuals from group II had the highest means for FF (Figure 3d), PF (Figure 3e) and SSC (Figure 3f) traits, related to fruit quality. For the Formosa groups, we see that genotypes in group XI had the best means for both traits of greatest importance to the crop (Figure 3).

For selection purposes, individuals in groups II, III and $\mathrm{XI}$ are more suitable, as they have allelic sources of interest related to the main traits. These individuals, when used in long-term recurrent selection, will increase the frequency of alleles for these traits. However, with the advancement of generations of these selected genotypes, it will be possible to identify genotypes that may be used as lines per se and/or as genitors of new hybrids, that is, the recurrent selection in papaya allows a wide range of options and genotypes for studies.

\section{$\mathrm{S}_{1}$ progenies selected for recombination}

The $\mathrm{S}_{1}$ progenies were selected for recombination at an early stage, and plants with higher fruiting and fruit size variation, from Solo-standard fruits to Formosa-standard fruits. Table 1 shows the means for the traits used to select the superior $40 \mathrm{~S}_{1}$ progenies.

Overall, the $40 \mathrm{~S}_{1}$ progenies selected were $138 \mathrm{~cm}$ tall, with the first fruit insertion close to $60 \mathrm{~cm}$ and a stem diameter close to $9 \mathrm{~cm}$. In terms of fruit yield, the selected progenies produced an average of 28 commercial fruits, three deformed fruits and three nodes without fruits. The selected $\mathrm{S}_{1}$ progenies had, on average, fruits with approximately $750 \mathrm{~g}$, and for $\mathrm{FW}$, the variation between the progenies was around $300 \mathrm{~g}$ to $1800 \mathrm{~g}$. Therefore, these progenies have genes that, when recombined to form the base population of the second cycle, will produce individuals with wide variability for the average fruit weight (FW) trait. In the early selection, the progenies produced an average of $20 \mathrm{~kg} \mathrm{plant}^{-1}$, and some of them reached close to $60 \mathrm{~kg}$ plant $^{-1}$. These results show the potential of the selected genetic material for recombination.

Figure 4 presents some photos of the fruiting of selected progenies. The most interesting here is the potential for fruit yield per axil. Some progenies produce two to three fruits per axil (Figure 4c, 4e), even producing up to four or five fruits per axil (Figure 4f). Although the number of
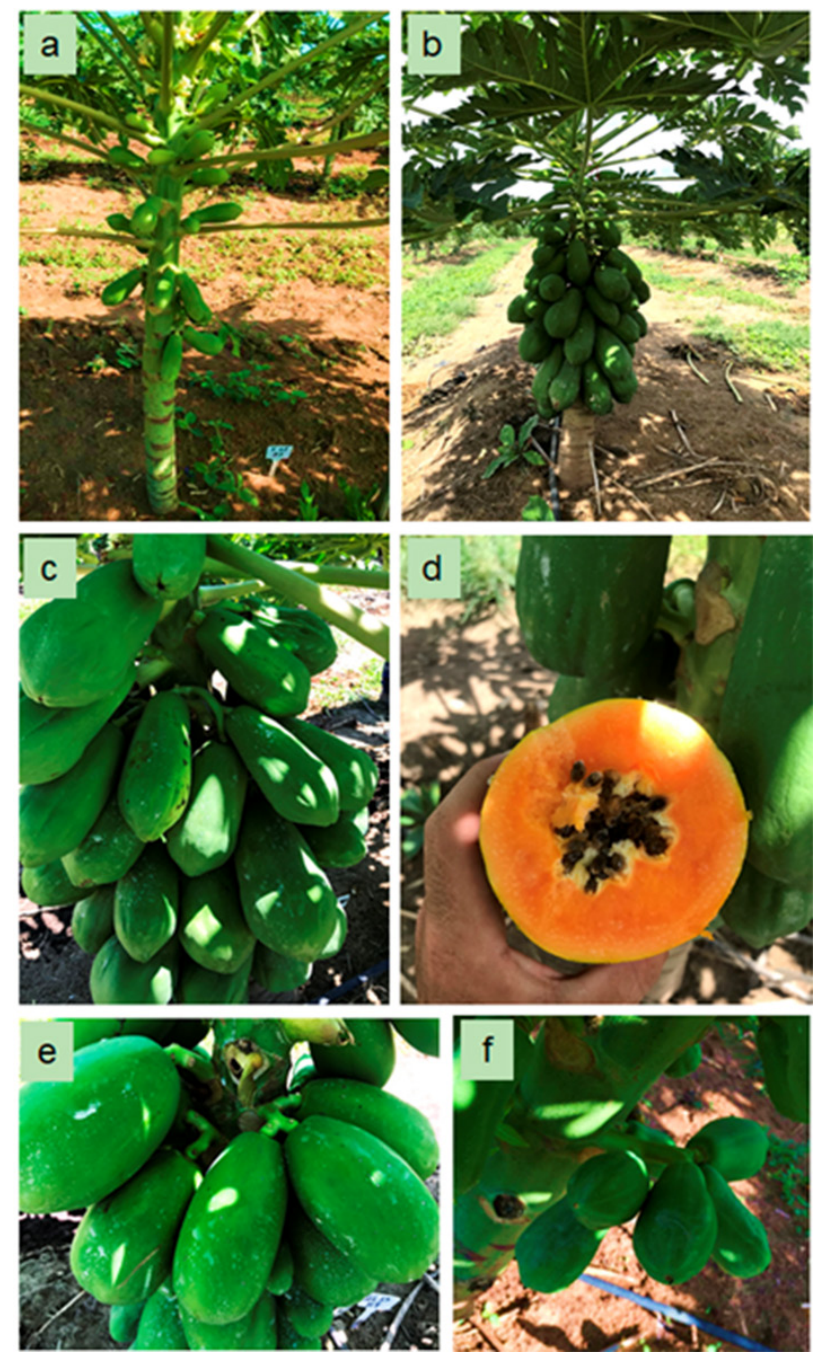

Figure 4. $\mathrm{S}_{1}$ progenies selected for recombination. a) UCP015-061 progeny with light-skinned phenotype; b) UCP015-188 progeny with low height of first fruit insertion; c) UCP015-188 progeny with good fruiting, three fruits per axil; d) Open fruit showing the orange phenotype for the pulp color; e) UCP015-015 progeny with good fruiting, 2 to 3 fruits in some axils; f) UCP015-226 progeny with excellent fruiting, 4 to 5 fruits per axil. 
fruits per axil is high, this is not seen as a problem but as a productive advantage, since these progenies produce fruits with long stalks, which does not impede their development (Figures 4c, 4e). Another interesting trait is the presence of genotypes with light-skinned fruit phenotype. This trait is important because the fruits tend to have less physiological spots (Figure 4a). Some selected progenies are segregating for the pulp color, and they are red, yellow and even orange pulp color progenies (Figure $4 d$ ).

The seeds of the base population of the second cycle UCP-C1 from recombination are ready for field sowing. In the next phase, molecular markers will be used to identify the sex and pulp color in the nursery stage, taking to the field only those plants with the desired phenotype, that is, hermaphrodite and red-fleshed seedlings.

Analyzing the first cycle of recurrent selection, we conclude that the beginning of the program was very successful, especially in the formation and genetic constitution of the UCP-CO base population, which demonstrated wide genetic variability for several evaluated traits. The use of heterogeneous dioecious progenies as a source of genes for resistance to the main diseases and for genetic variability, and the pollen mixture of elite genotypes from commercial hybrids, contributed to the observed results, mainly due to the genetic variability obtained in the resulting population. Although recurrent selection is a long-term breeding process, the results obtained in the first cycle allow the selection of some genotypes in the short term, as genitors of new hybrids or even as a line per se.

It is also concluded that, although papaya crop relatively demands large areas per plant and a long period of evaluation, the recurrent selection is feasible to be applied. It is an excellent alternative for the continuous generation of variability and new cultivars, capable of responding to the challenges of the crop in the short, medium and long term.

\section{ACKNOWLEDGMENTS}

We would like to thank the company CALIMAN AGRICOLA for the support in conducting and developing the work of papaya plant breeding, as well as the research support organizations CAPES, CNPq and FAPERJ.

\section{REFERENCES}

Alvares CA, Stape JL, Sentelhas PC, Gonçalves JLM and Sparovek G (2013) Koppen's climate classification map for Brazil. Meteorologische Zeitschrift 22: 711-728.

Barragán-Iglesias J, Méndez-Lagunas LL and Rodríguez-Ramírez J (2018) Ripeness indexes and physicochemical changes of papaya (Carica papaya L.cv. Maradol) during ripening on-tree. Scientia Horticulturae 236: $272-278$.

Barros GB, Aredes FAS, Ramos HCC, Santa-Catarina R and Pereira MG (2017) Combining ability of recombinant lines of papaya from backcrossing for sexual conversion. Revista Ciência Agronômica 48: $166-174$.

Cardoso DL, Luz LN, Macêdo CMP, Gonsalves LSA and Pereira MG (2014) Heterosis in papaya: inter and intragroup analysis. Revista Brasileira de Fruticultura 36: 610-619.

Cortes DFM, Santa-Catarina R, Azevedo AON, Poltronieri TPS, Vettorazzi JCF, Moreira NF, Ferreguetti GA, Ramos HCC, Viana AP and Pereira MG (2018) Papaya recombinant inbred lines selection by image-based phenotyping. Scientia Agricola 75: 208-215.

Cortes DFM, Santa-Catarina R, Barros GBA, Arêdes FAS, Silveira SF, Ferreguetti GA, Ramos HCC, Viana AP and Pereira MG (2017) Modelassisted phenotyping by digital images in papaya breeding program. Scientia Agricola 74: 294-302.

Cortes DFM, Santa-Catarina R, Vettorazzi JCF, Ramos HCC, Viana AP and
Pereira MG (2019) Development of superior lines of papaya from the Formosa group using the pedigree method and REML/Blup procedure. Bragantia 78: 1-11.

Damasceno Junior PC, Pereira TNS, Silva FF, Viana AP and Pereira MG (2008) Comportamento floral de híbridos de mamoeiro (Carica papaya L,) avaliados no verão e na primavera. Revista Ceres 55: 310-316.

FAOSTAT - Food and Agriculture Organization (2021) Corporate statistical database. Available at <http://www.fao.org/faostat/en/\#data/QC/ visualize>. Accessed on April 07, 2021.

Hallauer AR, Miranda Filho JB and Carena MJ (2010) Quantitative genetics in maize breeding. Springer, New York, 663p.

Huerta-Ocampo JÁ, Osuna-Castro JA, Lino-López GJ, Barrera-Pacheco A Mendoza-Hernández G, De León-Rodríguez A and Barba de la Rosa AP (2012) Proteomic analysis of differentially accumulated proteins during ripening and in response to $1-\mathrm{MCP}$ in papaya fruit. Journal of Proteomics 77: 2160-2169.

Hull FH (1945) Recurrent selection for specific combining ability in corn. Journal of the American Society of Agronomy 37: 134-145.

IBGE - Instituto Brasileiro de Geografia e Estatística (2020) Produção agrícola municipal, 2019 Available at <http://www.ibge.gov.br/ home/>. Accessed on October 12, 2020.

Ide CD, Pereira MG, Viana AP and Pereria TNS (2009) Use of testers for combining ability and selection of papaya hybrids. Crop Breeding 
and Applied Biotechnology 9: 60-66.

Luz LN, Pereira MG, Barros FR, Barros GBA and Ferreguetti GA (2015) Novos híbridos de mamoeiro avaliados nas condições de cultivo tradicional e no semiárido brasileiro. Revista Brasileira de Fruticultura 37: 159-171.

Luz LN, Santa-Catarina R, Barros GBA, Barros FR, Vettorazzi JCF and Pereira MG (2018a) Adaptability and stability of papaya hybrids affected by production seasonality. Crop Breeding and Applied Biotechnology 18: $357-364$.

Luz LN, Vettorazzi JCF, Santa-Catarina R, Barros FR, Barros GBA, Pereira MG and Cardoso DL (2018b) Sensory acceptance and qualitative analysis of fruits in papaya hybrids. Anais da Academia Brasileira de Ciências 90: 3693-3703.

Malik R, Sharma H, Sharma I, Kundu S, Verma A, Sheoran S, Kumar R and Chatrath R (2014) Genetic diversity of agro-morphological characters in Indian wheat varieties using GT biplot. Australian Journal of Crop Science 8: 1266-271.

Ming R, Hou S, Feng Y, Yu Q, Dionne-Laporte A, Saw JH, Senin P, Wang W, Ly BV, Lewis KLT, Salzberg SL, Feng L, Jones MR, Skelton RL, Murray JE, Chen C, Qian W, Shen J, Du P, Eustice M, Tong E, Tang H, Lyons E, Paull RE, Michael TP, Wall K, Rice DW, Albert H, Wang M-L, Zhu YJ, Schatz M, Nagarajan N, Acob RA, Guan P, Blas A, Wai1 CM, Ackerman CM, Ren Y, Liu C, Wang J, Wang J, Na J-K, Shakirov EV, Haas B, Thimmapuram J, Nelson D, Wang X, Bowers JE, Gschwend AR, Delcher AL, Singh R, Suzuki JY, Tripathi S, Neupane K, Wei H, Irikura B, Paidi M, Jiang N, Zhang W, Presting G, Windsor A, Navajas-Pérez R, Torres MJ, Alex Feltus F, Porter B, Li Y, Max Burroughs A, Luo M-C, Liu L, Christopher DA, Mount SM, Moore PH, Sugimura T, Jiang J, Schuler MA, Friedman V, Mitchell-Olds T, Shippen DE, dePamphilis CW, Palmer JD, Freeling M, Paterson AH, Gonsalves D, Wang L and Alam M (2008) The draft genome of the transgenic tropical fruit tree papaya (Carica papaya Linnaeus). Nature 452: 991-996.

Ming R, Yu Q and Moore PH (2007) Sex determination in papaya. Seminars in Cell \& Developmental Biology 18: 401-408.

Ming R, Yu Q, and Moore PH (2012) "Papaya genome and genomics". In Schnell RJ and Priyadarshan PM (eds) Genomics of tree crops. Springer, New York, p. 241-259.

Miranda DP, Ramos HCC, Santa-Catarina R, Vettorazzi JCF, Santana JGS, Poltronieri TPS, Pirovani AAV, Azevedo AON, Duarte RP, Rodrigues AS, Bohry D and Pereira MG (2021) Topcross hybrids in papaya (Carica papaya L.): evaluation of the potential for increasing fruit quality in new cultivars. Archives of Agronomy and Soil Science 67: 1-14.

Moreira NF, Pereira TNS, Santa Catarina R, Cortes DFM, Vettorazzi JCF, Ramos HCC, Viana AP and Pereira MG (2019) Quantification of floral abnormalities in a population generated from sexual polymorphism aiming at recurrent selection in papaya. Bragantia 78: 158-165.

Nascimento AL, Schmildt O, Ferreguetti GA, Krause W, Schmildt ER, Cavatte PC and Amaral JAT (2019) Genetic diversity of segregating Carica papaya genotypes using the Ward-MLM strategy. Genetic and Molecular Research 18: gmr18186.
Pereira MG, Luz LN, Santa-Catarina R, Ramos HCC, Pereira TNS, Barros GBA, Ferreguetti GA, Vivas M, Cortes DFM, Vettorazzi JCF, Azevedo AON, Silveira SF, Oliveira JG and Viana AP (2019b) UC10: a new early Formosa papaya cultivar. Crop Breeding and Applied Biotechnology 19: 131-134.

Pereira MG, Luz LN, Santa-Catarina R, Ramos HCC, Pereira TNS, Barros GBA, Ferreguetti GA, Vivas M, Cortes DFM, Vettorazzi JCF, Azevedo AON, Silveira SF, Oliveira JG and Viana AP (2019c) 'UC14': a new papaya cultivar with intermediate fruit size. Crop Breeding and Applied Biotechnology 19: 226-229.

Pereira MG, Poltronieri TPS, Pereira TNS, Ramos HCC, Santa-Catarina R., Vettorazzi JCF, Aredes FAZ, Boechat MSB, Venâncio TM, Azevedo AON, Cortes DFM, Moreira NF, Bohry D, Silveira SF, Vivas M and Ferreguetti GA (2019a) Twenty-two-year papaya breeding program: from breeding strategy establishment to cultivar development. Functional Plant Breeding Journal 1: 9-27.

Ramos HCC, Pereira MG, Silva FF and Viana AP (2011a) Seasonal and genetic influences on sexual expression in segregating papaya population derived from backcross. Crop Breeding and Applied Biotechnology 11: 97-105.

Ramos HCC, Pereira MG, Silva FF, Gonçalves LSA, Pinto FO, De Souza Filho GA and Pereira TSN (2011b) Genetic characterization of papaya plants (Carica papaya L.) derived from the first generation of backcross. Genetic and Molecular Research 10: 393-403.

Ramos HCC, Pereira MG, Viana AP, Luz LN, Cardoso DL and Ferreguetti GA (2014) Combined selection in backcross population of papaya (Carica papaya L.) by the mixed model methodology. American Journal of Plant Sciences 05: 2973-2983.

Santa-Catarina R, Cortes DFM, Vettorazzi JCF, Poltronieri TPS, Barros GBA, Arêdes FAS, Azevedo AON, Ramos HCC and Pereira MG (2019) Combining ability for fruit yield and quality in papaya recombinant inbred lines from the sexual conversion backcrossing. Euphytica 215: 54-164.

Santa-Catarina R, Cortes DFM, Vettorazzi JCF, Ramos HCC, Ferreguetti GA and Pereira MG (2018) Image-based phenotyping of morphoagronomic traits in papaya fruits (Carica papaya L. THB var.). Australian Journal of Crop Science 12: 1750-1756.

Santa-Catarina R, Pereira MG, Vettorazzi JCF, Cortes DFM, Poltronieri TPS, Azevedo AON, Moreira NF, Miranda DP, Moraes R, Pirovani AAV, Ramos HCC, Vivas M and Viana AP (2020a) Papaya (Carica papaya L.) S1 family recurrent selection: Opportunities and selection alternatives from the base population. Scientia Horticulturae 260: 108848.

Santa-Catarina R, Vettorazzi JCF, Cortes DFM, Santana JGS, Poltronieri TPS, Miranda DP, Pirovani AAV, Moreira NF, Vivas M and Pereira MG (2020b) Phenotypic characterization of recurrent selection S1 Papaya (Carica papaya L.) families by multivariate approach. Euphytica 216: 1-13.

Silva FF, Pereira MG, Damasceno Júnior PC, Pereira TNS, Viana AP, Daher RF, Ramos HCC and Ferreguetti GA (2007a) Evaluation of the sexual 
expression in segregation $\mathrm{BC} 1$ papaya population. Crop Breeding and Applied Biotechnology 7: 16-23.

Silva FF, Pereira MG, Ramos HCC, Damasceno Júnior PC, Pereira TNS and Ide CD (2007b) Genotypic correlations of morpho-agronomic traits in papaya and implications for genetic breeding. Crop Breeding and Applied Biotechnology 7: 345-352.

Silva FF, Pereira MG, Ramos HCC, Damasceno Júnior PC, Pereira TNS, Gabriel APC, Viana AP and Ferreguetti GA (2008a) Selection and estimation of the genetic gain in segregating generations of papaya (Carica papaya L.). Crop Breeding and Applied Biotechnology 8: 1-8.

Silva FF, Pereira MG, Ramos HCC, Damasceno Júnior PC, Pereira TNS, Viana AP, Daher RF and Ferreguetti GA (2008b) Estimation of genetic parameters related to morphoagronomic and fruit quality traits of papaya. Crop Breeding and Applied Biotechnology 8: 65-73.
Vettorazzi JCF, Santa-Catarina R, Poltronieri TPS, Cortes DFM, Azevedo AON, Miranda DP, Santana JGS, Ramos HCC and Pereira MG (2021) Combining ability of recombined F4 papaya lines: a strategy to select hybrid combination. Scientia Agricola 78: e20190191.

Vivas M, Silveira FV, Vivas JMS, Viana AP, Amaral Júnior AT and Pereira MG (2014) Seleção de progênies femininas de mamoeiro para resistência à mancha-de-phoma via modelos mistos. Bragantia 73: 446-450.

Vivas M, Silveira SF, Vivas JMS and Pereira MG (2012) Pathometry, genetic parameters and papaya progenies reaction to black-spot disease. Bragantia 71: 235-238.

Vivas M, Silveira SF, Vivas JMS and Pereira MG (2013) Prediction of genetic gain and progenies selection of papaya for resistance to black-spot. Tropical Plant Pathology 38: 142-148. 